\title{
Antarctic krill as a source of dissolved organic carbon to the Antarctic ecosystem
}

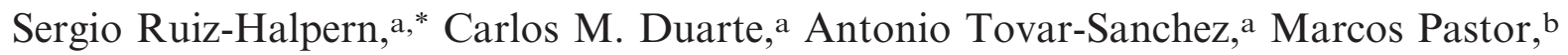 \\ Burkhard Horstkotte, ${ }^{a}$ Sebastien Lasternas, ${ }^{a}$ and Susana Agustía
}

\begin{abstract}
a Department of Global Change Research, Instituto Mediterráneo de Estudios Avanzados (IMEDEA), Consejo Superior de Investigaciones Científicas-Universitat de les Illes Balears (CSIC-UIB), Esporles, I. Balears, Spain

b Departamento de Acústica y Geofísica Unidad de Tecnología Marina-Consejo Superior de Investigaciones Científicas (UTM-CSIC), Barcelona, Catalunya, Spain
\end{abstract}

\begin{abstract}
The role of krill as a source of dissolved organic matter in the Southern Ocean was tested through a series of experiments performed around the Antarctic Peninsula. These experiments revealed high but variable release rates of dissolved material (carbon and nutrients), supplying, on average, $150 \mathrm{mmol}$ dissolved organic carbon (DOC) $\mathrm{m}^{-2} \mathrm{~d}^{-1}$, which is comparable with that supported by phytoplankton. Krill support, on average, $73 \%$ of the combined krill + phytoplankton production of DOC in the ecosystem, implying the importance of krill in conditioning the productivity of the Southern Ocean. However, the contribution of krill as a source of DOC varied greatly because of the patchy distribution of both krill and primary producers in the region, ranging from $98 \%$ to $10 \%$ of the combined (krill + phytoplankton) DOC release rates. These results suggest that rapid decline in krill standing stocks associated with reduced ice cover may have major consequences for microbial communities in the ecosystem, since bacterial carbon demand often exceeds the DOC supplied by phytoplankton in coastal areas of the Southern Ocean, with potential unforeseen consequences in the carbon balance of the Southern Ocean.
\end{abstract}

Antarctic krill, Euphasia superba, with an estimated abundance of $\sim 170 \times 10^{9} \mathrm{~kg}$ (Atkinson et al. 2004), is arguably one of the most abundant animals on Earth (Nicol and Endo 1997; Siegel 2005), acting as a major node in the Antarctic food web, where it is consumed by a broad range of Antarctic megafauna (Murphy 1995). Provided its high biomass and production, krill must also play a key role in the recycling of materials, thereby affecting the Antarctic microbial food web both as a consumer (Atkinson et al. 2001) and as a source of necessary recycled materials (Tovar-Sanchez et al. 2007). Indeed, available evidence shows that krill plays a crucial role in recycling nitrogen, phosphorus, iron, and other metals in the Southern Ocean, contributing to the high primary productivity of these waters by supplying readily utilizable iron, phosphate, and ammonia (Ikeda and Mitchell 1982; TovarSanchez et al. 2007, 2009). Krill has been recently shown to play a key role in producing chromophoric dissolved organic matter (CDOM) (Ortega-Retuerta et al. 2009), providing indications that krill can play a significant role as a source of dissolved organic carbon (DOC) to the environment. Previous attempts to use CDOM measurements to infer DOC concentrations yielded adequate correlations only when DOC dynamics are controlled by terrestrial or riverine inputs. Moreover, because the mechanisms that drive CDOM and DOC distribution are uncoupled in oceanic areas, no conversion factors found in the literature can be used to estimate DOC from CDOM in the Southern Ocean (Nelson and Siegel 2002; Coble 2007). Hence, quantitatively assessing the role of Antarctic krill as a source of DOC to the microbial food web is particularly important, because bacterial communities in Antarctica are

\footnotetext{
*Corresponding author: Sergio.ruiz@imedea.uib-csic.es
}

quite sparse relative to the biomass of autotrophs compared with other ocean areas (Duarte et al. 2005). Possible explanations for the low abundance, and activity, of bacteria in the Southern Ocean include substrate limitation (Church et al. 2000; Pomeroy and Wiebe 2001) resulting in low growth rates that render bacterial communities prone to grazer control (Duarte et al. 2005). Evaluations of DOC release by Antarctic phytoplankton communities showed that release rates vary between $3 \%$ and $47 \%$ of primary production (Morán and Estrada 2002). These values fall within the range of those reported for other oceans, although it is not uncommon to find higher values (Karl et al. 1998; Myklestad 2000; Teira et al. 2003). This release of DOC by phytoplankton is generally found to be coupled to bacterial production in the Southern Ocean (Morán et al. 2001). However, there is also evidence of decoupling between bacterial and phytoplankton production in coastal areas (Morán et al. 2002), such as the Gerlache Strait (Bird and Karl 1999).

It is well established that there are a suite of mechanisms that can lead to DOC release into the water column, providing the necessary DOC to sustain carbon consumption rates, when these exceed primary production (Nagata 2000). Grazers (protozoa and zooplankton) contribute to the DOC pool by sloppy feeding, excretion, egestion, and dissolution of fecal pellet material (Strom 1997). Viral infections of bacteria and phytoplankton can also compose an important fraction of the DOC released to the environment (Nagata 2000). Protozoans account for as much as $50 \%$ of total DOC, whereas zooplankton produce as much as $12 \%$ (Nagata 2000). Several experiments demonstrate the importance of copepods in the production of DOC (Strom et al 1997; Urban-Rich 1999; Møller 2007). However, to the best of the author's knowledge, there are 
no quantitative estimates of DOC contributed by zooplankton in the Antarctic peninsula. As one of the most abundant species in this environment, krill must then play a fundamental role in supplementing bacterial carbon demand (BCD) above the limits imposed by DOC directly delivered by autotrophs. Therefore, its role as a source of DOC in the Southern Ocean ecosystem has not yet been elucidated.

Here we evaluate experimentally the rates and dynamics of DOC and nutrient release by Antarctic krill, as the major zooplanktonic species in this environment (Ross et al. 1996), and their stoichiometry with nitrogen and phosphorus, and evaluate the importance of krill-derived DOC relative to the DOC produced by phytoplankton. We do so on the basis of a cruise, Aportes Atmosféricos de Carbono Orgánico y Contaminantes al Océano Polar (ATOS)Antarctic, conducted on board the RV Hespérides around the Antarctic Peninsula.

\section{Methods}

The release of DOC, $\mathrm{NH}_{4}^{+}$, total nitrogen $(\mathrm{TN})$, and total phosphorous (TP) by Antarctic krill (E. superba) was examined between January and February 2009, time of peak krill abundance (Siegel 2000), during the ATOSAntarctic cruise on board the RV Hespérides along the Antarctic Peninsula sector of the Southern Ocean. All experiments were done along the Antarctic Peninsula, including the Weddell Sea, the Antarctic Sound, the Bransfield Strait, down to the Bellingshausen Sea, south of the Polar Circle (Fig. 1).

Krill individuals for excretion experiments were collected within the upper $50 \mathrm{~m}$ at eight stations with contrasting oceanographic characteristics (Fig. 1). Krill swarms were located using a Simrad ${ }^{\mathrm{TM}}$ EK60 multifrequency echosounder. The specimens for the experiments were caught using an Isaacs-Kidd midwater trawl net (1-cm mesh size) trawled for 20 min at the depth where krill swarms were located (typically about 20-30-m depth). Krill specimens were caught whenever a large enough swarm was identified, and as such, the time of day for the experiments varied among the different dates (Table 1). Time of day of experiments was not expected to affect krill feeding rates, since they feed continuously in the field (Antezena et al. 1982; Morris et al. 1983). After retrieval, live krill were placed in a 50-liter plastic container filled with seawater and held for a short time (typically less than $5 \mathrm{~min}$ ) before the experiments were performed. The release experiments followed the procedure described by Tovar-Sanchez et al. (2007). Before the krill were captured, surface seawater (1$m$ depth) was pumped from a small boat through a Cole Parker peristaltic pump using acid-cleaned Teflon ${ }^{\circledR}$ tubing coupled to C-flex tubing, filtered through an acid-cleaned polypropylene cartridge filter $\left(0.22 \mathrm{~mm}\right.$, MSI-Calyx $\left.{ }^{\circledR}\right)$, and collected in 2-liter bottles for the release experiments. Four randomly selected krill individuals were transferred into each of three to five acid-washed 2-liter polycarbonate bottles, so that 12 to 20 individuals were used per station, with a total of 144 individuals tested along the cruise. Experimental (containing krill) and control bottles (with-

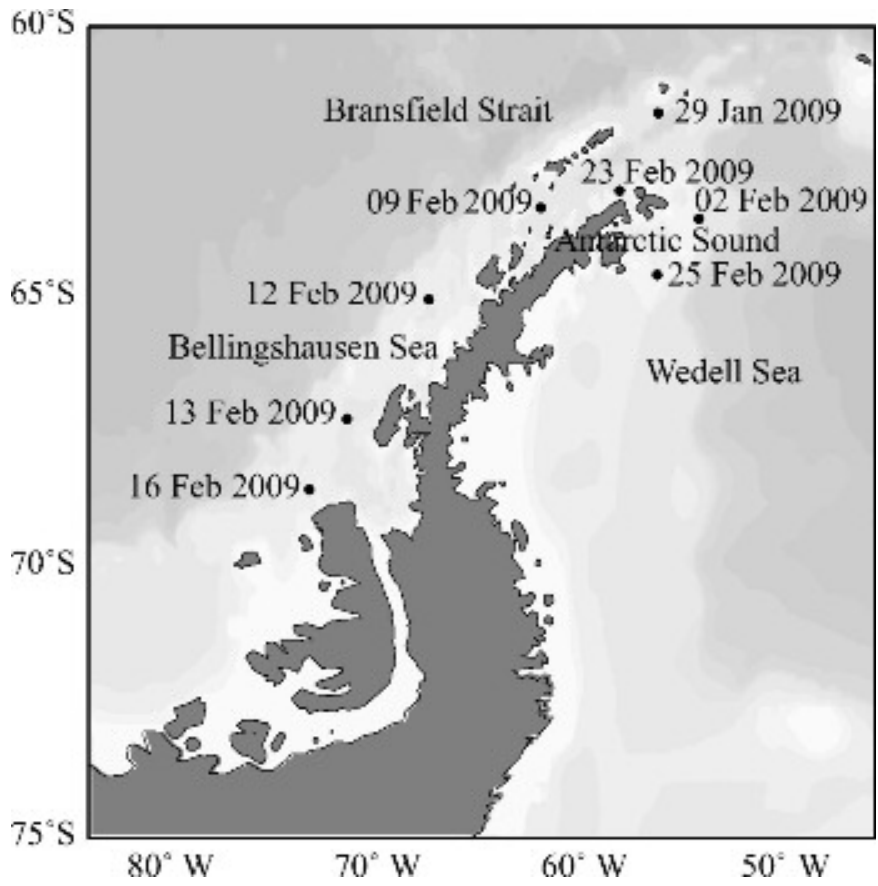

Fig. 1. Location and date of sampling of the eight experimental stations spaced along the Antarctic peninsula.

out krill) were incubated in the dark, at in situ temperature, for $30,60,90,120$, and $240 \mathrm{~min}$. At each time step water samples were collected from a different bottle and analyzed for DOC, $\mathrm{NH}_{4}^{+}, \mathrm{TN}$, and TP. Krill were then retrieved and kept frozen until analyzed in the laboratory, where specimens were thawed, dried to constant weight at $60^{\circ} \mathrm{C}$ in a drying oven, and weighed to the nearest milligram. For DOC, water was filtered through a GF/F filter and $10-\mathrm{mL}$ aliquots transferred to duplicate glass ampoules, precombusted at $450^{\circ} \mathrm{C}$ for $5 \mathrm{~h}$, sealed under flame, and stored until analysis in the laboratory. DOC analyses were performed on a Shimadzu total organic carbon (TOC)5000 or TOC-Vcsh following high-temperature catalytic oxidation techniques (Spyres et al. 2000). Standards provided by D. A. Hansell and W. Chen (University of Miami) of $2 \mu \mathrm{mol} \mathrm{L}^{-1}$ and $44 \mu \mathrm{mol} \mathrm{L}^{-1}$ TOC were used to assess the accuracy of the estimates.

Water for TN and TP analysis was collected in duplicate in high-density polyethylene tubes and kept frozen until analyzed in a Bran-Luebe AA3 autoanalyzer using standard methods (Hansen and Koroleff 1999) with ultraviolet mineralization (Oms et al. 2003). $\mathrm{NH}_{4}^{+}$concentrations were determined spectrofluorometrically onboard using a Shimadzu spectrofluorimeter (Kérouel and Aminot 1997). Krill abundance was estimated using a SimradTM EK60 multifrequency echosounder. Working frequency was $38 \mathrm{kHz}$ with a $256-\mu$ s sampling interval, $1024 \mu$ s pulse duration, and $2425-\mathrm{Hz}$ bandwidth. The data obtained were processed using SonarData Echoview 4 software. A maximum depth of $100 \mathrm{~m}$ and $80-\mathrm{dB}$ minimum target strength, applying a time-varied gain function, was used to identify the krill targets. Finally, the data were subjected to a 100-m depth cell and a 1-min duration analysis. The number of targets detected down to $100-\mathrm{m}$ cells was 


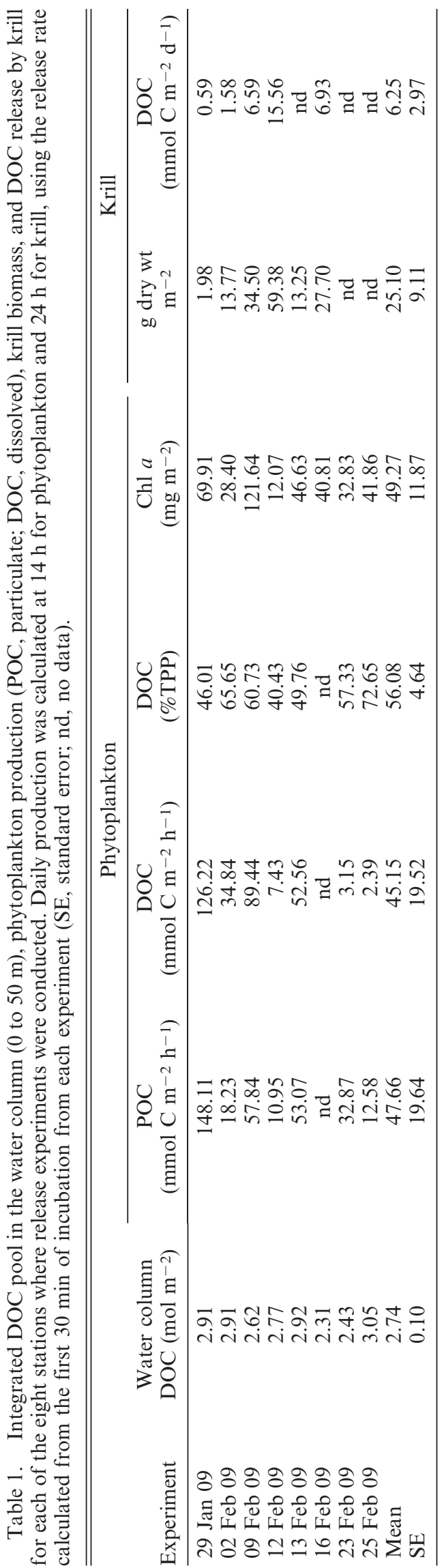

counted at 1-min intervals, and the volume sampled by the beam calculated. Krill biomass was estimated as the product of the individual weight (wt) of krill in each station and the density (individuals $\mathrm{m}^{-3}$ ) of krill within 10$\mathrm{m}$ depth bins, and vertically integrated within the top $50 \mathrm{~m}$ of the water column, the layer containing most of the specimens.

In situ primary production, total and particulate, was measured by the ${ }^{14} \mathrm{C}$ technique (Steeman-Nielsen 1952) as described in Lasternas and Agustí (in press). Water was sampled at least from three depths including the surface $(1 \mathrm{~m})$, the subsurface $(5 \mathrm{~m})$, and the deep chlorophyll maximum (DCM), in all cases shallower than $50 \mathrm{~m}$. Water collected at these depths was transferred into transparent (light) and dark 150-mL polycarbonate bottles, and inoculated with $100 \mu \mathrm{Ci}$ activity of a ${ }^{14} \mathrm{C}$ working solution. Inoculated bottles were suspended at the corresponding depths from a drifting buoy and incubated in situ for $4 \mathrm{~h}$. At the end of the incubation period duplicate $5-\mathrm{mL}$ aliquots were transferred into $20-\mathrm{mL}$ scintillation vials for the determination of total primary production (TPP). The remaining volume was filtered through $0.22 \mu \mathrm{m}$ mesh membrane filters (cellulose membrane filters) of $25-\mathrm{mm}$ diameter to determine particulate primary production (PPP $>0.22 \mu \mathrm{m})$. Samples were acidified with $100 \mu \mathrm{L}$ of $10 \%$ $\mathrm{HCl}$ and shaken for $12 \mathrm{~h}$ to remove inorganic ${ }^{14} \mathrm{C}$. Then, $10 \mathrm{~mL}$ of scintillation cocktail (Packard Ultima Gold XR) were added to TPP vials and the disintegrations per minute were counted after $24 \mathrm{~h}$ with a scintillation counter (LS 5801, Beckman). DOC production by phytoplankton was calculated as the difference between TPP and PPP (Morán et al. 2001). The incubations contain the full microplankton community and, hence, the DOC release measurements include contributions from protist grazing and viral lysis as well (Nagata 2000). However, for simplicity we refer to these estimates as phytoplankton DOC release.

Chlorophyll $a$ (Chl $a$ ) concentration was determined by filtering 50-mL samples onto 25-mm diameter Whatmann $\mathrm{GF} / \mathrm{F}$ filters from each depth at each station. After filtration, filters were placed in tubes with a $90 \%$ acetone solution for $24 \mathrm{~h}$ to extract the pigment. Chl $a$ fluorescence was measured in a Shimadzu RF-5301 PC spectrofluorimeter, calibrated with pure Chl $a$ as described in Parsons et al. (1984).

\section{Results}

The experiments conducted at eight different stations along the Antarctic Peninsula (Fig. 1) showed that krill release large amounts of DOC and nutrients, although the release rates decline rapidly with time (Fig. 2). Krill released two-thirds of the total DOC released along the full length of the incubations within $1.5 \mathrm{~h}$ after the onset of the experiment (Fig. 3). The geometric mean initial rate of DOC release was $202 \mu \mathrm{mol} \mathrm{C} \mathrm{g} \mathrm{dry} \mathrm{weight} \mathrm{(dry} \mathrm{wt)}{ }^{-1} \mathrm{~h}^{-1}$ (Table 2), although this rate was highly variable among experiments (Table 1). Nutrient release rates followed the same trend as those for DOC release (Fig. 2, Table 2). The initial excretion products released by krill were relatively nutrient depleted, as evidenced by high $\mathrm{C}: \mathrm{N}$ and $\mathrm{C}: \mathrm{P}$ 


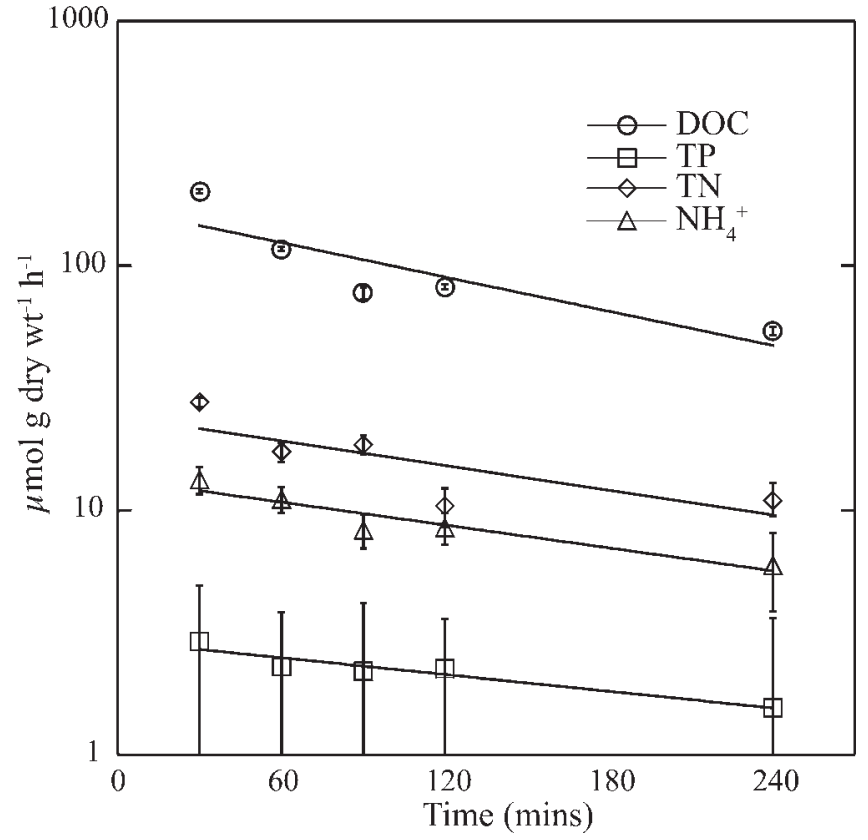

Fig. 2. Fit of the geometric mean $\pm \mathrm{SD}$ release rates for the eight experiments. DOC $=170 e^{-0.0054 \mathrm{time}}, R^{2}=0.75$. $\mathrm{TN}=$ $24 e^{-0.0039 \text { time }}, R^{2}=0.68$. TP $=2.9 e^{-0.0026 \text { time }}, R^{2}=0.88$. $\mathrm{NH}_{4}^{+}=13 e^{-0.0036 \text { time. }} R^{2}=0.89$. All $p<0.05$ except TN $p>0.05$.

ratios (median 73.93 and 140.36, respectively), with the $\mathrm{C}: \mathrm{N}$ ratio declining along the course of the incubations (Table 3).

Phytoplankton primary production integrated down to $50 \mathrm{~m}$ was highly variable across the stations sampled, ranging from 18.4 to $274.3 \mathrm{mmol} \mathrm{C} \mathrm{m}^{-2} \mathrm{~d}^{-1}$, with a mean

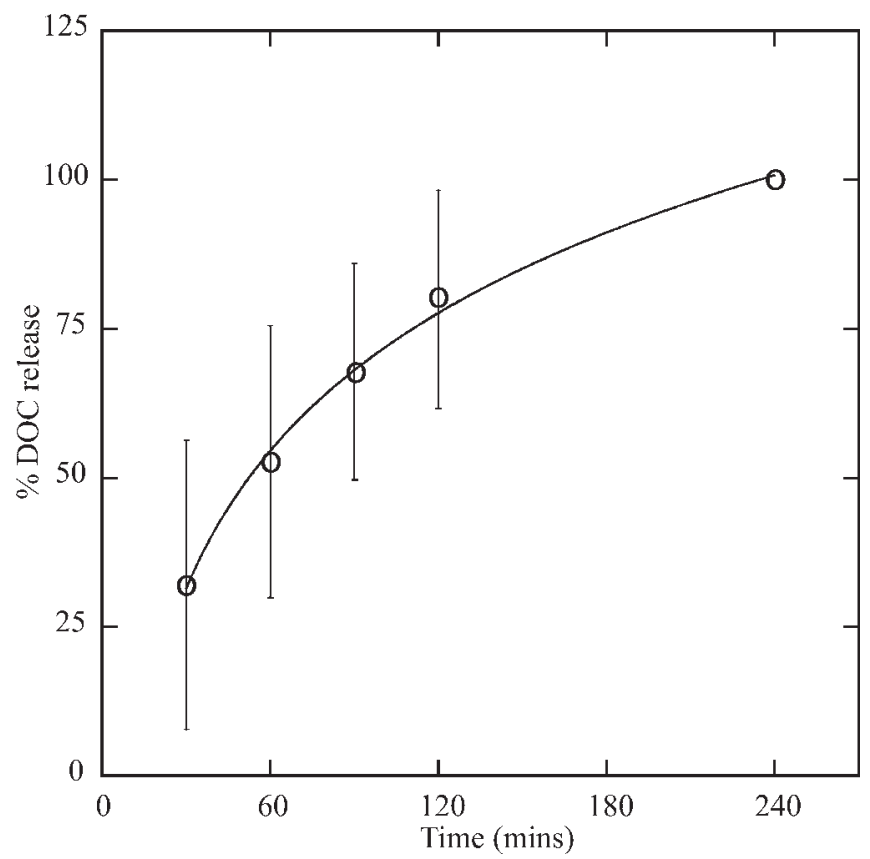

Fig. 3. Mean \pm SD percentage of total DOC released at each time step, calculated from the release rate of each experiment at each time step.
Table 2. Geometric mean and geometric standard deviation (SD) of DOC and nutrient release rates by Antarctic krill in $\mu \mathrm{mol} g$ dry $\mathrm{wt}^{-1} \mathrm{~h}^{-1},(n=8$ experiments). The rates reported are those calculated after 30 min of incubation.

\begin{tabular}{lrc}
\hline \hline & Mean & SD \\
\hline DOC & 202.00 & 4.15 \\
TN & 27.72 & 1.35 \\
TP & 2.92 & 2.05 \\
$\mathrm{NH}_{4}^{+}$ & 13.35 & 1.66 \\
\hline
\end{tabular}

( \pm SE) DOC percent extracellular release of $56.08 \% \pm$ $4.64 \%$ (Table 3) of TPP. Particulate organic carbon (POC) and DOC production profiles showed variable rates, spanning two orders of magnitude with a peak at the DCM except for 12 February 2009 (Fig. 4), where a large bloom occurred (Table 1). Krill standing stock averaged $25.1 \pm 9.1 \mathrm{~g}$ dry wt $\mathrm{m}^{-2}$ and was calculated to release on average $150 \pm 71.3 \mathrm{mmol} \mathrm{C} \mathrm{m} \mathrm{C}^{-2} \mathrm{~d}^{-1}$ as DOC. Chl $a$ standing stock averaged $49.27 \pm 11.87 \mathrm{mg} \mathrm{C} \mathrm{m}^{-2}$, with an average release of DOC of $55.44 \pm 16.26 \mathrm{mmol} \mathrm{C} \mathrm{m}^{-2} \mathrm{~d}^{-1}$ (Table 3). However, only two of the four stations where both rates could be calculated did krill DOC release exceed TPP (Table 1). The combined flow of DOC from phytoplankton and krill averaged $205.4 \pm 77.7 \mathrm{mmol} \mathrm{C} \mathrm{m}^{-2} \mathrm{~d}^{-1}$ compared with an average DOC standing stock of $2.7 \pm$ $0.1 \mathrm{~mol} \mathrm{C} \mathrm{m}^{-2}$ (Table 1).

\section{Discussion}

The data presented here highlight the important role that krill play in the Southern Ocean. Indeed, krill is recognized as the central node in the Antarctic ecosystem, providing a food source for higher-order consumers (whales, penguins, seals) (Murphy 1995), but also remineralizing nutrients and metals essential for phytoplankton growth (Ikeda and Mitchell 1982; Tovar-Sanchez et al. 2007). The results demonstrate that krill also play a key role as a source of DOC, thereby increasing the flow of carbon potentially available to support heterotrophic bacteria. Recent evidence that krill release substantial amounts of colored dissolved organic matter, with doubling times of less than a day at high krill densities (Ortega-Retuerta et al. 2009), provided indications for potentially high DOC release. Yet,

Table 3. Median and standard error of the mean (SE) for the carbon-to-nutrient and nitrogen-to-phosphorus ratios at each time step along the duration of the experiments $(n=$ 8 experiments)

\begin{tabular}{|c|c|c|c|c|c|c|}
\hline \multirow{2}{*}{$\begin{array}{l}\text { Time } \\
(\min )\end{array}$} & \multicolumn{2}{|c|}{$\mathrm{C}: \mathrm{N}$} & \multicolumn{2}{|c|}{$N: P$} & \multicolumn{2}{|c|}{$C: P$} \\
\hline & Median & SE & Median & $\mathrm{SE}$ & Median & $\mathrm{SE}$ \\
\hline 30 & 73.93 & 62.86 & 4.07 & 5.62 & 140.36 & 226.44 \\
\hline 60 & 30.03 & 9.54 & 10.41 & 3.76 & 251.13 & 47.79 \\
\hline 90 & 39.54 & 29.46 & 4.87 & 5.34 & 169.65 & 286.37 \\
\hline 120 & 23.13 & 33.61 & 5.56 & 4.18 & 127.29 & 77.71 \\
\hline 240 & 20.25 & 15.36 & 3.91 & 6.26 & 97.06 & 26.65 \\
\hline
\end{tabular}


Antarctic krill DOC release
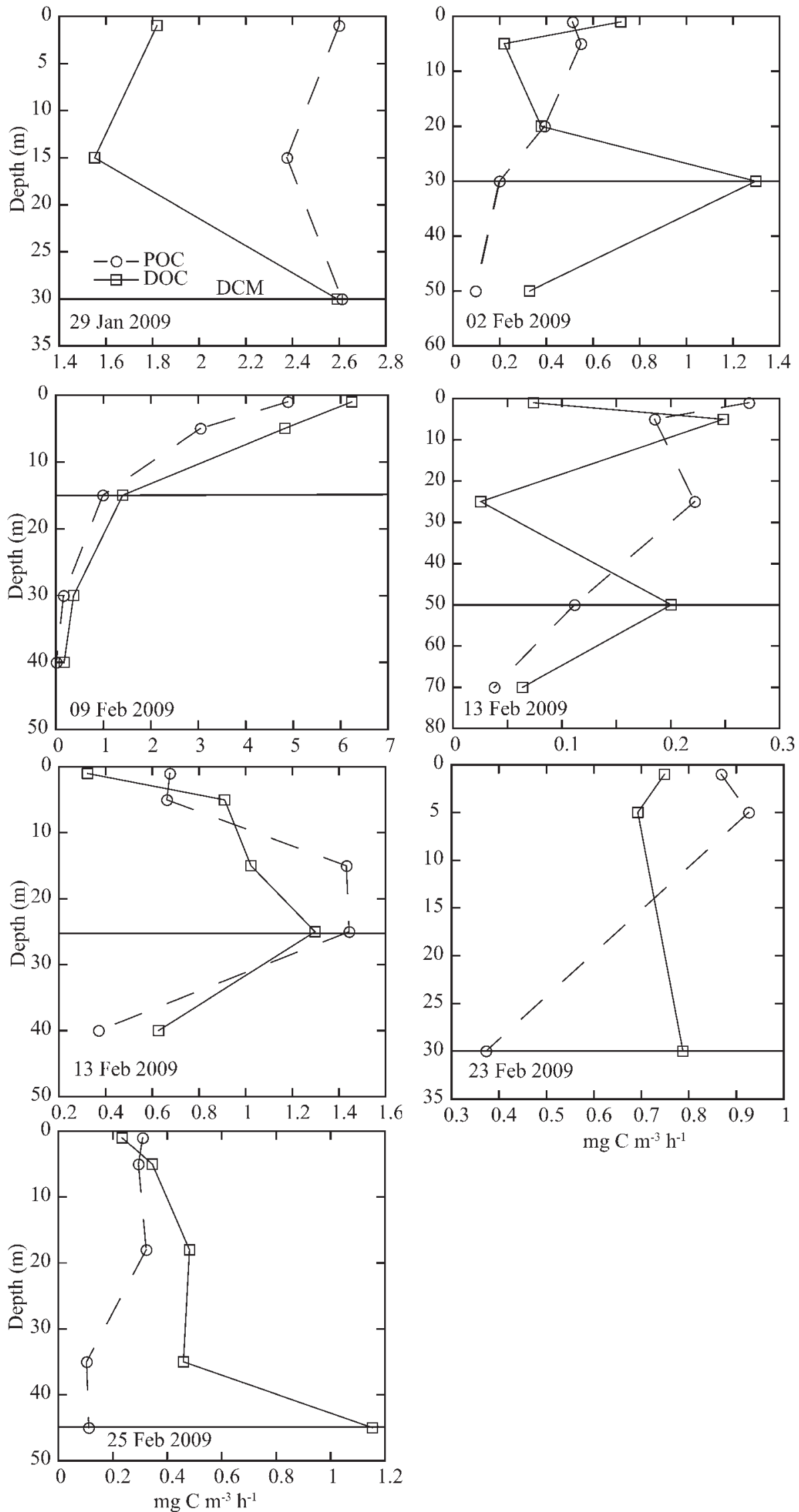

Fig. 4. Vertical profiles of POC and DOC primary production. Horizontal line represents the DCM, always shallower than $50 \mathrm{~m}$. 
the use of CDOM as a proxy for DOC is only supported when riverine discharge controls the distribution of both DOC and CDOM. Attempts to calculate DOC from CDOM in other environments are flawed by large uncertainties, largely due to decoupled dynamics of both fractions, and a variable background of noncolored DOC in the water (Coble 2007). The results presented here quantitatively demonstrate that krill play an important role in the flux of dissolved organic matter.

As demonstrated for nutrient and metal release (TovarSanchez et al. 2007, 2009), the release of DOC by krill decreased rapidly over time when the animals are removed from prey, as was the case for the experiments conducted here. This is in agreement with the reported krill gut clearance rates of $<1 \mathrm{~h}$ (Morris et al. 1983; Clarke et al. 1988). As krill are constantly feeding (Morris et al. 1983), they are able to maintain high DOC release rates throughout the day, releasing, on average, $16 \%$ of their carbon biomass as DOC per day (calculated from the data in Table 1). The depletion in $\mathrm{N}$ and, to a lesser extent, $\mathrm{P}$ relative to DOC of krill release products (Table 3) could limit bacterial use in the absence of inorganic nutrients. However, inorganic nutrient concentrations are characteristically high in Antarctic waters (Timmermans et al. 2001) so that low nutrient-to-DOC release ratios should not limit use of krill-derived DOC by bacteria.

Krill was found to be an important source of recycled DOC in the system, supporting high rates of DOC release, comparable with those supported by phytoplankton (Table 1). Provided that submarine light availability at the time the study was conducted (January-February 2009) allowed photosynthetic rates to proceed over $14 \mathrm{~h}$, whereas krill feed, and therefore release DOC, throughout $24 \mathrm{~h}$ (Morris et al. 1983). Whereas krill and phytoplankton release rates varied greatly, rates normalized to biomass ( $\mathrm{g}$ dry wt for krill and Chl $a$ for phytoplankton) were relatively uniform, with normalized rates varying threeand fourfold, respectively. Phytoplankton DOC release rate estimates include that released directly by phytoplankton as well as that mediated by protist grazing. However, DOC release rates by zooplankton other than krill were not assessed, so that the release rates presented here should be considered minimum estimates of the total DOC released by zooplankton. The contribution of krill to DOC release is much greater than the average value of $12 \%$ of DOC production contributed by zooplankton calculated by Nagata (2000) for the global ocean, even though the estimate derived here refers to krill alone and does not include the contribution from other components of the zooplankton community, such as copepods. Phytoplankton DOC release rates ranged from $40.43 \%$ to $72.65 \%$ of TOC production, well above the range (3\% to $47 \%$ ) reported for the same region by Morán and Estrada (2002). Yet, the combined DOC production by phtytoplankton and krill was well above that of phytoplankton alone, averaging 205 $\pm 77.7 \mathrm{mmol} \mathrm{C} \mathrm{m}-2 \mathrm{~d}^{-1}$, of which krill contributed $73.03 \%$ $\pm 21 \%$ (calculated from Table 3 ). However, the contribution of krill as a source of DOC varied greatly because of the patchy distribution of both krill and primary producers in the region, ranging from $98 \%$ to $10 \%$ of the combined (krill + phytoplankton) DOC release rate. Indeed, Morán et al. (2002) reported that BCD often exceeds the carbon supplied as DOC by phytoplankton in Antarctic coastal waters, and suggested that such carbon was supplied by terrestrial inputs (Morán et al. 2002). However, the results presented here indicate that krill is an important source of DOC in the Antarctic ecosystem hitherto unaccounted for.

The efficient recycling of nutrients by krill has led to the argument that these animals play a fundamental role in conditioning the Southern Ocean pelagic ecosystem to maintain it at a high productivity level (Smetacek 2006; Tovar-Sanchez et al. 2007; Nicol et al. 2010). The results presented here suggest that krill not only recycle nutrients to support phytoplankton growth, but they do, in fact, retain nutrients differentially (Table 2) so that their contribution as an important source of DOC potentially used by bacteria, implying an important role of krill in the maintenance of microbial food webs, may be greater than anticipated. With gut cleareance rates of less than an hour, krill are expected to deliver DOC and nutrients at the initial rates and stoichiometry measured, resulting in a buildup of carbon relative to nitrogen, available to the microbial community. Moreover, whereas krill consume a broad range of prey, from phytoplankton to copepods (Hamner et al. 1983; Price et al. 1988), bacteria are too small to be removed by krill, except when associated with detritus ingested by krill. Hence, krill provides resources, DOC, and nutrients for bacteria without, unlike for phytoplankton, impinging severe losses on the bacterial community. Moreover, the characteristically patchy distribution of krill (Siegel 2000) suggests that DOC release by krill should play an important role as a source of patchiness in microbial activity in the region.

The importance of krill as a source of carbon for bacteria suggests that the recent observations of the decline in krill standing stock associated with reduced ice cover (Loeb et al. 1997; Atkinson et al. 2004) may have more pervasive effects in the Antarctic ecosystem than hitherto believed, affecting not only the metazoan food web directly, but the microbial food web as well. In addition to their potential effect on bacteria, the release of DOC by krill is sufficient in magnitude to play a significant role in carbon cycling in Antarctic waters. Indeed, the combined DOC release by phytoplankton and krill, with a contribution of krill that matches or exceeds that of phytoplankton, indicates that the DOC pool, which is particularly small in Antarctic waters (Kähler et al. 1997), may turn over rather fast, at minimum rate of $10 \% \pm 2 \% \mathrm{~d}^{-1}$ (calculated from Table 1 ). Hence, the decline of krill stocks may have effects on the remineralization of organic carbon. On the basis of the results presented here, we therefore hypothesize that krill release products must greatly stimulate Antarctic bacterial communities with unforeseen consequences to the carbon balance of the Southern Ocean, a hypothesis that awaits experimental test.

\section{Acknowledgments}

We thank the commander and crew of the RV Hespérides for dedicated and professional assistance, the personnel of the Unidad de Tecnología Marina (UTM) for highly professional technical 
support, Ana Massanet for help in the experimental setup, Miquel Alcaraz for help with krill collections, Juan Carlos Alonso for nutrient analysis, and Pedro Echeveste for Chl $a$ analysis. This is a contribution to the Aportes Atmósfericos de Carbono Orgánico y Contaminantes al Océano Polar (ATOS) project funded by the Spanish Ministry of Science and Innovation under the scope of the International Polar Year (IPY).

\section{References}

Antezena, T., K. Ray, and C. Melo. 1982. Trophic behavior of Euphausia superba Dana in laboratory conditions. Polar Biology 1: 77-82.

Atkinson, A., V. Siegel, E. Pakhomov, and P. Rothery. 2004. Long-term decline in krill stock and increase in salps within the Southern Ocean. Nature 432: 100-103, doi:10.1038/ nature02996

—, M. J. Whitehouse, J. Priddle, G. C. Cripps, P. Ward, And M. A. Brandon. 2001. South Georgia, Antarctica: A productive, cold-water, pelagic ecosystem. Mar. Ecol. Prog. Ser. 216: 279-308, doi:10.3354/meps216279

BIRD, D. F., AND D. M. KARL. 1999. Uncoupling of bacteria and phytoplankton during the austral spring bloom in Gerlache Strait, Antarctic Peninsula. Aquat. Microb. Ecol. 19: 13-27, doi:10.3354/ame019013

Church, M., D. Hutchins, And H. Ducklow. 2000. Limitation of bacterial growth by dissolved organic matter and iron in the Southern Ocean. Appl. Environ. Microb. 66: 455-466, doi:10.1128/AEM.66.2.455-466.2000

Clarke, A., L. B. Quetin, and R. M. Ross. 1988. Laboratory and field estimates of the rate of faecal pellet production by Antarctic krill, Euphausia superba. Mar. Biol. 98: 557-563, doi:10.1007/BF00391547

Coble, P. 2007. Marine optical biogeochemistry: The chemistry of ocean color. Chem. Rev. 107: 402-418, doi:10.1021/ cr050350+

Duarte, C. M., S. Agustí, D. Vaqué, N. S. R. Agawin, J. Felipe, E. O. Casamayor, and J. M. Gasol. 2005. Experimental test of bacteria-phytoplankton coupling in the Southern Ocean. Limnol. Oceanogr. 50: 1844-1854, doi:10.4319/lo.2005. 50.6.1844

Hamner, W. M., P. P. Hamner, S. W. Strand, and R. W. Gilmer. 1983. Behavior of Antarctic krill, Euphausia superba: Chemoreception, feeding, schooling, and molting. Science 220: 433-435, doi:10.1126/science.220.4595.433

Hansen, H. P., and F. Koroleff. 1999. Determination of nutrients, p. 159-226. In K. Grasshoff, K. Cremling, and M. Erhardt [eds.], Methods of seawater analysis. Wiley-VCH.

IkedA, T., AND A. W. Mitchell. 1982. Oxygen uptake, ammonia excretion and phosphate excretion by krill and other Antarctic zooplankton in relation to their body size and chemical composition. Mar. Biol. 71: 283-298, doi:10.1007/ BF00397045

Kähler, P., P. Buornsen, K. Lochte, and A. Antia. 1997. Dissolved organic matter and its utilization by bacteria during spring in the Southern Ocean. Deep-Sea. Res. II 44: 341-353, doi:10.1016/S0967-0645(96)00071-9

Karl, D. M., D. V. Hebel, K. Buörkman, and R. Letelier. 1998. The role of dissolved organic matter release in the productivity of the oligotrophic North Pacific Ocean. Limnol. Oceanogr. 43: 1270-1286, doi:10.4319/1o.1998.43.6.1270

Kérouel, R., And A. Aminot. 1997. Fluorometric determination of ammonia in sea and estuarine waters by direct segmented flow analysis. Mar. Chem. 57: 265-275, doi:10.1016/S0304-4203 (97)00040-6
Lasternas, S., and S. Agustí. In press. Phytoplankton community structure during the record arctic ice-melting of summer 2007. Is now available in the Polar Biology Online First section, doi:10.1007/s00300-010-0877-X

Loeb, V., V. Siegel, O. Holm-Hansen, R. Hewitt, W. Fraser, W. Trivelpiece, And S. Trivelpiece. 1997. Effects of sea-ice extent and krill or salp dominance on the Antarctic food web. Nature 387: 897-900, doi:10.1038/43174

Møller, E. F. 2007. Production of dissolved organic carbon by sloppy feeding in the copepods Acartia tonsa, Centropages typicus, and Temora longicornis. Limnol. Oceanogr. 52: 79-84, doi:10.4319/1o.2007.52.1.0079

Morán, X. A. G., And M. Estrada. 2002. Phytoplanktonic DOC and POC production in the Bransfield and Gerlache Straits as derived from kinetic experiments of ${ }^{14} \mathrm{C}$ incorporation. DeepSea. Res. II 49: 769-786, doi:10.1016/S0967-0645(01)00123-0

$\longrightarrow, \longrightarrow$, J. Gasol, And C. Pedrós-Alió. 2002. Dissolved primary production and the strength of phytoplanktonbacterioplankton coupling in contrasting marine regions. Microb. Ecol. 44: 217-223, doi:10.1007/s00248-002-1026-Z

- J. M. Gasol, C. Pedrós-Alió, and M. Estrada. 2001. Dissolved and particulate primary production and bacterial production in offshore Antarctic waters during austral summer: Coupled or uncoupled? Mar. Ecol. Prog. Ser. 222: 25-39, doi:10.3354/meps222025

Morris, D. J., P. Ward, AND A. Clarke. 1983. Some aspects of feeding in the Antarctic krill, Euphausia superba. Polar Biol. 2: 21-26, doi:10.1007/BF00258281

Murphy, E. J. 1995. Spatial structure of the Southern Ocean ecosystem: Predator-prey linkages in Southern Ocean food webs. J. Anim. Ecol. 64: 333-347, doi:10.2307/5895

Myklestad, S. M. 2000. Disolved organic carbon from phytoplankton, p. 111-148. In P. Wangersky [ed.], The handbook of environmental chemistry, v. 5 part D. Springer-Verlag.

Nagata, T. 2000. Production mechanisms of dissolved organic matter, p. 121-152. In D. Kirchman [ed.], Microbial ecology of the oceans. John Wiley and Son.

Nelson, N. B., And D. A. Siegel. 2002. Chromophoric DOM in the open ocean, p. 547-573. In D. Hansell and C. A. Carlson [eds.], Biogeochemistry of dissolved organic matter. Academic Press.

Nicol, S., A. Bowie, S. Jarman, D. Lannuzel, K. M. Meiners, And P. VAn de Merwe. 2010. Southern Ocean iron fertilization by baleen whales and Antartic krill. Fish Fish. 11: 203-209, doi:10.1111/j.1467-2979.2010.00356.x

_ AND Y. ENDO. 1997. Krill fisheries of the world. Food \& Agriculture Organization.

Oms, M. T., A. Cerdà, And V. Cerdà. 2003. Sequential injection system for on-line analysis of total nitrogen with UVmineralization. Talanta 59: 319-326, doi:10.1016/S0039-9140 (02)00520-9

Ortega-Retuerta, E., T. K. Frazer, C. M. Duarte, S. RuizHalpern, A. Tovar-Sanchez, J. M. Arrieta, and I. Reche. 2009. Biogeneration of chromophoric dissolved organic matter by bacteria and krill in the Southern Ocean. Limnol. Oceanogr. 54: 1941-1950, doi:10.4319/lo.2009.54.6.1941

Parsons, T. R., Y. Maita, and C. M. Lalli. 1984. A manual of chemical and biological methods for seawater analysis. Pergamon Press.

Pomeroy, L. R., and W. J. Wiebe. 2001. Temperature and substrates as interactive limiting factors for marine heterotrophic bacteria. Aquat. Microb. Ecol. 23: 187-204, doi:10.3354/ame023187

Price, H. J., K. R. Boyd, And C. M. Boyd. 1988. Omnivorous feeding behavior of the Antarctic krill Euphausia superba. Mar. Biol. 97: 67-77, doi:10.1007/BF00391246 
Ross, R. M., L. B. Quetin, and C. M. Lascara. 1996. Distribution of Antarctic krill and dominant zooplankton west of the antarctic peninsula, p. 199-217. In R. M. Ross, E. E. Hoffman, and L. B. Quetin [eds.], Foundations for ecological research west of the Antarctic Peninsula, Antarctic Research Series, v. 70. American Geophysical Union.

Siegel, V. 2000. Krill (Euphasia superba) demography and variability in abundance and distribution. Can. J. Fish. Aquat. Sci. 53: 151-167, doi:10.1139/cjfas-57-S3-151

. 2005. Distribution and population dynamics of Euphausia superba: Summary of recent findings. Polar Biol. 29: 1-22, doi:10.1007/s00300-005-0058-5

SmetaceK, V. 2006. Research highlights. Nature 440: 130-131, doi:10.1038/440151a

Spyres, G. S. G., P. J. Worsfold, E. P. A. Miller, M. Mimmo, AND A. J. Miller. 2000. Determination of dissolved organic carbon in seawater using high-temperature catalytic oxidation techniques. TrAC 19: 498-506.

SteEmann-Nielsen, E. J. 1952. The use of radioactive carbon $\left({ }^{14} \mathrm{C}\right)$ for measuring organic production in the sea. Cons. Perm. Int. Explor. Mer 18: 117-140.

Strom, S. L., R. Benner, S. Ziegler, and M. J. Dagg. 1997. Planktonic grazers are a potentially important source of marine dissolved organic carbon. Limnol. Oceanogr. 42: 1364-1374, doi:10.4319/1o.1997.42.6.1364
Teira, E., M. J. Pazó, M. Quevedo, M. V. Fuentes, F. X. Niell, and E. Fernandez. 2003. Rates of dissolved organic carbon production and bacterial activity in the eastern North Atlantic Subtropical Gyre during summer. Mar. Ecol. Prog. Ser. 249: 53-67, doi:10.3354/meps249053

Timmermans, K. R., AND others. 2001. Growth rates of large and small Southern Ocean diatoms in relation to availabaility of iron in natural seawater. Limnol. Oceanogr. 46: 260-266, doi:10.4319/lo.2001.46.2.0260

Tovar-Sanchez, A., C. M. Duarte, S. Hernández-León, and S. A. Sañudo Wilhelmy. 2007. Krill as a central node for iron cycling in the Southern Ocean. Geophys. Res. Lett. 34: L11601, doi:10.1029/2006GL029096

, — $\longrightarrow$, AND —. 2009. Impact of submarine hydrothermal vents on the metal composition of krill and its excretion products. Mar. Chem. 113: 129-136, doi:10.1016/ j.marchem.2009.01.010

URBAN-Rich, J. 1999. Release of dissolved organic carbon from copepod fecal pellets in the Greenland Sea. J. Exp. Mar. Biol. Ecol. 232: 107-124, doi:10.1016/S0022-0981(98)00104-X

Associate editor: Wade H. Jeffrey

Received: 05 May 2010 Accepted: 18 November 2010 Amended: 07 December 2010 